\title{
The Importance of Age in Development
}

\author{
Sibonginkosi Mazibuko
}

University of South Africa (Unisa) , Department of Development Studies, PO Box 2619, Johannesburg, 2000

Email: mazibsg@unisa.ac.za

\section{Doi:10.5901/mjss.2014.v5n20p2533}

\section{Abstract}

In terms of the sustainable livelihoods approach (SLA), sustainable livelihoods are achievable by the presence of five specific capital assets including human capital. This article shows that human capital needs to be expanded beyond education, training, skills and health. The research was conducted in one rural area of KwaZulu-Natal, South Africa. Using triangulation as well as target and random sampling methods, the study aimed to: (1) identify the capital assets of the people in that area; (2) identify the barriers that they still faced in taking an active role in the local tourism economy after a few years of democracy, and (3) also identify the economic opportunities that the local people could exploit. During the research it was found that young people had clearer and profound views about their conditions than the rest of the community members in terms of age differences. Based on the interviews with different categories of local community members, the article argues that young people in particular have clearer views about their conditions of poverty and unemployment. The article concludes therefore that age is critically fundamental in the realisation of sustainable human capital. In this regard, biological age should form part of the human capital component of the SLA.

Keywords: age, poverty, livelihoods, vulnerability, assets

\section{Introduction}

This article derives from the broader study the author conducted for the Doctor of Philosophae (PhD) degree in the area of AmaZizi, KwaZulu-Natal in South Africa. The study investigated the livelihoods of the rural community of AmaZizi adjacent to the Royal Natal National Park (RNNP) in the northern Drakensberg. This article argues that young biological age (as opposed to maturity age or psychological age for example) should be regarded as an asset in peoples' lives. The article shows that what happens to individuals at old biological age can be best explained in terms of what happened when they were young. In this regard, the article argues that poverty can be better prevented by arming people with necessary tools while they are still young. Using the sustainable livelihoods framework (Figure 1), this article shows for example that while education and skills are fundamental in securing people with improved lives, biological age determines how and to what extent people can learn new ways of doing things.

This article addresses the author's observation that the young people in the study area were found to be having more ideas than their elders about development in their area. The youths (between the ages of 16 and 20) showed better understanding and insight in the issues that affected their society than the interviewed focus groups of local councillors, traditional leaders and women crafters (see Table 1). This article then argues that young biological age is the crucial stage at which people can acquire the abilities that determine the extent to which individuals cope particularly at old age. It is also for this reason that education is also strongly considered here because we argue that capabilities can be better acquired at younger ages.

The sustainable rural livelihoods approach is even more appealing in the conditions of South Africa because of the structural triple evils of poverty, unemployment and inequality largely created by previous regimes. Nel $(2005$, p253) postulates that poverty and unemployment have contributed to unsustainable communities in rural areas and unsustainable service delivery in urban areas as people flock to towns and cities in search of better livelihoods. For example, in spite of the opportunities provided by the conservation areas at their doorsteps, the South African rural people adjacent to such areas, such as the people of AmaZizi in the northern Drakensberg, could not access them because of the previous discriminatory laws that ensured exclusion of indigenous African people from the broader economy. In these areas, with the exception of access to natural resources for handicrafts, the African populations could only wait for the few exploitative manual employment opportunities that trickled down from time to time.

The broader study from which this article derives then sought to firstly identify and critically understand the capital assets the people of AmaZizi possessed, secondly it sought to identify and analyse the barriers that local people still 
faced after a few years of democracy, and thirdly identify the economic opportunities that the local people could exploit.

\section{Background to the Study Area}

The African tribal rural communal area of AmaZizi lies at 28.44'S and 29.32'E adjacent to the Royal Natal National Park approximately forty-six kilometres southwest of Bergville, on the foot of the northern Drakensberg (Ukhahlamba) mountain range. It is situated also near the town of Bergville in KwaZulu-Natal, South Africa. The town, surrounded largely by white-owned commercial farms, is situated on the banks of the Uthukela (Tugela) River, with its source inside the Royal Natal National Park (RNNP). The area of AmaZizi is under the chieftaincy of Inkosi Mthetho Miya. The area is a grassland summer rainfall region of more than $805 \mathrm{~mm}$ rainfall per annum with very cold winters (Greyling and Huntley 1984).

According to Statistics South Africa (Stats SA) (2001), the area of AmaZizi had a total of $74 \%$ unemployment rate. As a result poverty was at its highest. In South Africa both poverty and unemployment are structural biased against the black majority of the country's inhabitants. They are based on race (affecting the black population in the main), gender (affecting black women largely) and age (affecting the black youth in particular) (Stats SA 2012). It is therefore no wonder the area of AmaZizi had such high levels of poverty and unemployment.

\section{Methodology}

The broader study used triangulation (employing both qualitative and quantitative methods). We conducted a survey of 108 households with semi-structured questions. After the survey, we conducted four focus group interviews. These interviews were based on open-ended questions around which discussions emanated. The views presented here are those of the focus group interviews we held with the local people. The groups were structured as follows: the first group consisted of the eight traditional leadership of izinduna (headmen), the second group was that of the democratically elected councillors, the third were the women crafters and the last group were the young people in the area. Each focus group had between eight and six members. While the groups of women crafters, headmen and councillors were selected using the target sample method, the youth participants were selected randomly. No tape recording was used and all the discussions were captured by the researcher manually. The researcher took the responsibility to transport all the participants from their homes and back from the venue at local tribal office which was used with the permission of the local inkosi (chief). None of the participants were paid anything for agreeing to take part in these interviews. Again, while the study posed no harm to participants or anyone, the researcher fully explained the objectives of the study to the participants and that they could opt to withdraw from participation if they so desired at any time.

\section{The Sustainable Livelihoods (SL): A Theoretical Framework}

Few concepts are as controversial as the concept of poverty. Poverty has been defined and or explained differently by different people. But what comes to light is the fact that each definition is either dictated by locational and or ideological inclination of organisations and individuals. Thus definitions range from capability deprivation, capitalist exploitation, cultural, intergenerational, structural, chronic, absolute, relative and subjective forms of poverty (Sen 1999; Carson \& Buther 1992, pp110-111; Haralambos 1985, pp140-144; Lauer 1989, pp238-239).

In this study, we take the view that in South Africa poverty is structural. This structure of poverty is pronounced in terms of race, gender and age in particular (Statistics SA 2012; Michaud \& Vencatachellum 2003, pp603\&605). It is also our view that in South Africa poverty is to a great extent man-made through discriminatory laws over the years of colonialism and settler-colonialism. Poverty was entrenched through deprivation of the country's black majority of access and ownership of key capital assets as explained by Mazibuko (2013). It is among this racial group that poverty, unemployment and inequality are most pronounced and among their females and young people in particular. This kind of poverty speaks to distributional justice. In other words, it is poverty that comes as result of injustice.

This explanation therefore justifies the use of the sustainable livelihoods approach (SLA) in an effort to explain and understand poverty in this article. The sustainable livelihoods framework refers to the five forms of capital assets (natural, human, financial, physical and social) as shown in Figure 1 that people possess. Carney (1998, pp3 \& 7) and Scoones (1998, pp7 - 8) explain the different forms of capital assets as follows: 
Figure 1: Sustainable livelihoods framework

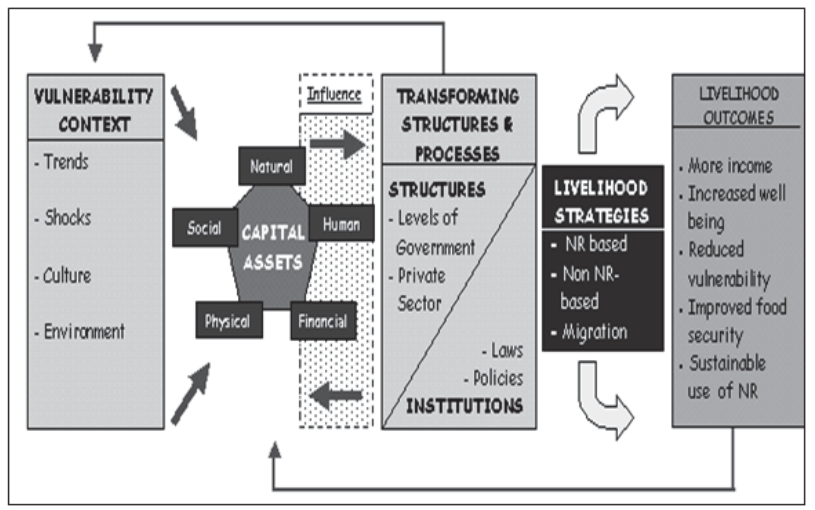

Source: Carney, 1998

- Human capital consists in education, skills, knowledge, health, and labour. Changes in human capital are likely to have tremendous effects on all other factors that account for as assets. At a household level, human capital is most likely to differ since household sizes are never the same or equal. The size of a household is one of the determining factors as what livelihood strategies to pursue.

- Financial capital consists in incomes, access to credit and any other financial means. Financial capital is a very versatile form of capital. Having money for example means that a household can afford to do many other things such as going to a doctor, buying enough food, send children to school and so on. A household that has access to financial capital is therefore better placed to achieve its well-being than otherwise.

- . Natural capital consists in land, water, biological diversity. Lack of access to productive land for example may greatly compromise the livelihoods of some families. So with the natural resources. Due to their conditions of poverty, the poor households may find themselves degrading the natural environment such that even the soil nutrients are never recovered.

- Physical capitals are livestock, machinery, communications, infrastructure and housing. With on proper road infrastructure for example, people struggle to reach markets. Poor housing and lack of safe water supply could mean people spend most of their time collecting water from far either for building their homes or for other domestic uses. Such situations remove people from engaging in productive activities.

- Social capital refers to ability to socialise with other people for example in local organisations, access to information and any form of social support either from family or friends. Social capital is also much related to social groups or class. Here, networks are created and for the poor, these also provide a way of escaping shocks such as funeral costs. Friends, family and or club members will always be at hand to help. Social capital also goes to the level of politics. Politics has a major allocative role in a society.

Important as they are, assets also exist within a particular context of vulnerability. The framework refers to trends, shocks and cultural practices as influencing livelihoods. Trends refer for example to stocks of resources, population density, technology, politics and economics. Shocks could for example be in the form of job losses, conflicts and climate while cultural trends are concerned with the effects culture has on how people manage and choose their livelihoods (Carney 1998, p11). Understood within the vulnerability context, how assets are utilised is also the function of institutional settings. If certain laws and policies are introduced in society, a particular structural development would emerge which lends itself to either sustainable or unsustainable livelihoods outcomes as depicted in the framework.

\section{Human Capital: Biological Age as an Asset in Development}

In particular, the form of capital asset that is relevant for this paper is the human capital. Pretty $(2003$, p13) defines human capital as the total capabilities of individuals. Such capabilities are represented in their stock of knowledge, skills, health and nutrition and they are made better by the ability to access schools and medical services for example. In that 
way, their leadership and organisational skills are also developed.

The crucial role of human capital was also identified by the settler-colonial governments in South Africa and they used it to retard development instead of advancing it. Through the education system of Bantu Education introduced in 1953, children of black people were to be sent to differentiated schools (Michaud \& Vencatachellum 200, p603) that taught an education that prepared them to serve the interests of white supremacy. These schools were underfunded and employed largely under-qualified staffers. Specific black universities were also built. They had no faculties of either medicine or engineering. This wrong, wasteful and harmful education (Machlup 1982, p9) further ensured that black people's skills were inferior and through the Wages Act black people were legally required to work for less pay than their white counter-parts and accept largely jobs of lower grades (Mazibuko 2013). Low wages simply served to re-enforce the system of Bantu Education. Without enough wages, parents of black children could not afford to send their children to alternative private schools which at least tolerated black people. Similarly with health, black people were restricted to receiving health services from the specifically designated clinics and hospitals with similar under-qualified staffers. The poor health services black people receive become evident in the high mortality rates of both children and adults. The life expectancy for black people is 57 years while that of whites is 75 years.

The DFID (www.livelihoods.org) says:

\begin{abstract}
Human capital represents the skills, knowledge, ability to labour and good health that together enable people to pursue different livelihood strategies and achieve their livelihood objectives. At a household level human capital is a factor of the amount and quality of labour available; this varies according to household size, skill level, leadership potential, health status, etc. (DFID, 1999)
\end{abstract}

The DFID's definition also takes us to the same conclusions that sustainable livelihoods can only be achieved through sensible human capital assets. However, nowhere is age mentioned in the above. Age becomes an asset when we realise that, in addition to what Pretty and the DFID for example say, the younger the people the easier it is for them to learn new skills and absorb new information required for their (future) livelihoods. Age is also critical in rural settings where physical features of people are crucial. Rural work is in most cases hard work which requires physical strength. The long distances that people have to walk are better undertaken by the young. The older the people the lesser they are able to reach certain places removed from them because they then lack the strength to endure the long tedious walks.

Because human capital depends so much on the educational skills that people acquire mainly while they are still young, age becomes a factor here. That the settler-colonial regimes chose to use education as a pillar of the apartheid system was precisely to instil inferiority in the minds of children. Black children had to grow into adulthood only knowing that their role was to serve the white people. Instead of focusing human capital to contributing to economic growth (Abbas \& Mujahid-Mukhtar 2001), in South Africa this asset was misused to pursue an unsustainable socially constructed and engineered system that not only tears society apart but it has created a situation where the black majority has actually become a liability in the economy.

Age is also a basic criterion in determining the dependency ratio. If the majority of the population is young especially below legal working age, the higher the dependency ratio becomes, and therefore the lower the population ratio that should ensure survival of the rest. The situation equally applies where the majority falls in the category of the old. If the generation is too old, that could mean that fewer people are available for the labour force. The old generation therefore also constitutes dependency ratio. The situation is better if those of the working age are younger and therefore still can carry the role of being carriers of the rest. In this regard, Lauer $(1989, \mathrm{p} 249)$ refers to the concept of autonomy. At both young and old ages, people have little autonomy in what they do because of the means at their disposal. For example, both a child at ten and an adult at eighty years of ages are constrained by a number of factors such as finances and opportunity.

Age becomes a factor in development as it impacts on people's ability to learn and to be productive. A number of studies show that the peak time for productivity in people is in their $50 \mathrm{~s}$. Thereafter their productivity tends to decline, a condition Machlup (1982, pp7-8) refers to as depreciation of human capital, unless they are highly skilled and experienced to keep with technological changes in their workplaces. This decline in productivity is also accompanied by declining capabilities to learn new techniques. Even employers are inclined to preferring people who are younger (less than fifty years old) so that even if there is an economic downturn, firms will tend to offer retrenchment packages beginning with those who are regarded as old in particular (Lauer 1989, p272), because they are either regarded as less productive or they are more expensive than the young and productive labour force. Older people are further said to be more vulnerable to ailments which all contribute to poor economic performance both in individual firms and the national economies (Guillemette 2003, p 5, Skirbekk 2003, pp4 - 8, Tauer 1995, pp63-69 and Youmans 1977, p88). This may be 
construed as being prejudiced against older persons, but it is largely the reality of the markets.

Governments have increasingly made schooling compulsory at certain grades. Such policy could be severely limited in the face of poverty as found in the study area. Faced with a situation where for example a parent has to either feed their children or send them to school, with little or no resources, a parent could logically choose to withdraw their child from schooling (Lauer 1989, p251). Therefore, in terms of the sustainable livelihoods framework, institutions could either aid development or reinforce poverty leading to unsustainable livelihood outcomes. Notwithstanding this, at schoolgoing ages, people are able to secure their futures by being able to do the things they may not be able to do at later stages of life such as learning new ways of doing things (acquiring skills). It is the argument of this article that poverty can therefore be eradicated from the young ages of people by providing them with necessary skills. Many of the poor are usually found to have little or no skills. As a result they are forced to hard labour throughout their lives, and when they can no longer perform those labour intensive duties markets discard them in preference for younger labour force. All things equal, it is better to acquire the skills earlier in life when people have no other demands on their lives except those of youth.

Van Schalkwyk (2008, pp264, 267 and 272) points out that "public institutions (in South Africa) have an obligation to ensure service delivery to all its citizens ... water, sanitation and electricity'. This author further points out that many of the poor are not able to pay for these services while the municipalities are faced with challenges of providing sustainable social services and infrastructure. The question of ensuring that people are empowered at young ages could then assist in reducing the inabilities that make them severely dependent on public institutions for services particularly at old age. As van Schalkwyk points out, the inability to pay is largely a result of the lack of the means to do so. What needs to be addressed is making sure that people are enabled to pay for the services. The point could be how that should happen. Of course employment is the key issue, but employment needs to be based on relevant skills in order to be sustainable. In other words, skills ensure sustainable jobs and these in turn ensure that the provision of services becomes sustainable. Even municipalities particularly in rural areas are themselves poorer because they serve poor people who cannot pay. So there is a great link between what skills people possess and the services they get. People with better skills have better incomes and consequently enjoy better service delivery because then the municipalities have a wider source of reliable tax base from which to derive revenues.

Noting that sustainable livelihoods are a product of a combination of assets that individuals (or households) possess or should possess in order to realise their livelihood outcomes, this relationship can be expressed as follows:

$$
\begin{aligned}
& S L=f(n+f+s+p+h) \\
& \text { where: } \\
& S L=\text { sustainable livelihood, } \\
& n=\text { natural capital } \\
& f=\text { financial capital } \\
& p=\text { physical capital } \\
& h=\text { human capital } \\
& s=\text { social capital }
\end{aligned}
$$

\section{Results and Discussion}

While the interviews involved various groupings, this article reports on the value the young people could add to understanding poverty and deprivation in a particular rural community. This study found that the youngsters of AmaZizi were the most conscious of the problems facing their society. These young people were more profound in their understanding of current trends affecting their society. On this basis, the article argues that since development is about people rather than objects, sustainable livelihoods can be better achieved by ensuring that the young people become actively involved in their communities and that they are prepared for their future roles.

The youths that were interviewed for this project were more outspoken and critical of their situation. It is not that they disagreed with the rest of the interviewees, but they seemed to understand their conditions in a rather profound manner. For example the researcher asked the question on what role traditional leadership has in local development. These young people were able to show the strengths and weaknesses of the system as it affected them. They presented practical analytical instances where the traditional leadership had succeeded and they were also very clear on what they thought should happen. They were able to point out instances of nepotism and mal-practices. They drew differences between the roles of traditional leadership and the elected local councillors. They indicated that these structures both have important roles. They pointed out the lack of employment opportunities and the ever shrinking living space, and pointed to more urgent needs for additional land. These young people, while recognising the value of agriculture, they 
were under no illusion about the fact that it is unsustainable in their situation of limited access to farmland. Without exception, they all looked forward to finding their livelihoods outside their own area. This point was evidenced also by the high percentage of residents that had remittances as their main source of income. The survey we conducted had indicated that remittances (42\%) were the second highest source of income after state social grants (68\%), while formal employment (20\%) took the third place (Mazibuko 2010, p146).

Table 1: Views from the focus groups

Source: Mazibuko (2010, p101)

\begin{tabular}{|l|c|c|c|c|}
\hline Activity & Traditional leaders & Local councillors & Women crafters & Youth \\
\hline Main local livelihoods & 8 & 5 & 10 & 10 \\
\hline Key assets & 2 & 2 & 3 & 8 \\
\hline Opportunities & 5 & 6 & 4 & 10 \\
\hline Constraints & 2 & 1 & 3 & 3 \\
\hline Total & 17 & 14 & 20 & 31 \\
\hline & & & & \\
\hline
\end{tabular}

In Table 1 we show the views of the participants in the study. The questions were based on four key areas as indicated under the heading 'Activity' in the table. Looking at the total responses provided by each focus group, the youths were able to identify a total of thirty-one compared to the rest of the other groups. An interesting observation here was the fewer responses provided by the elected councillors and the traditional leaders. In this regard, many profound questions could be asked. The researcher therefore concluded that age plays an important role in understanding certain issues that relate to development. To this effect, young biological age constitutes a critical element of human capital which is required to ensure a sustainable livelihood.

According to the Statistics South Africa (Stats SA 2001) the age structures of AmaZizi (Wards 6 and 7) were as indicated in the Figures 2(a) and 2(b):

Figure 2(a): Gender by age in Ward 6, AmaZizi

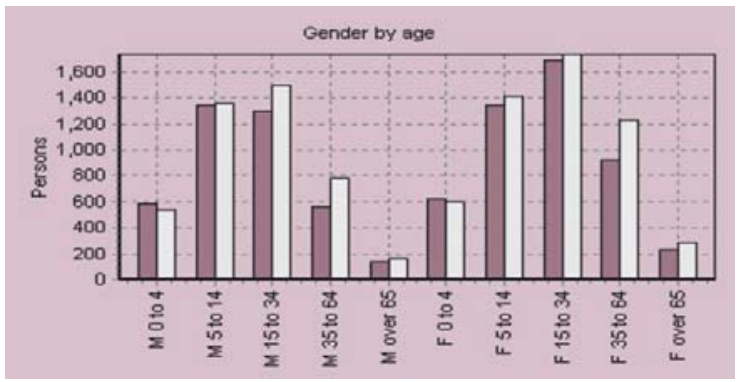

Source: Statistics South Africa 2001

Figure 2(b): Gender by age in Ward 7, AmaZizi

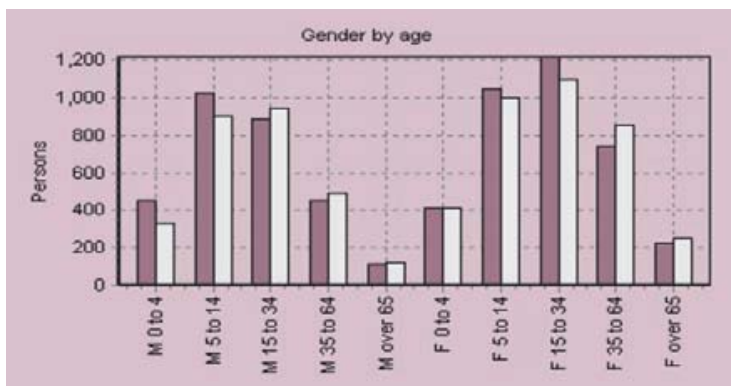

Source: Statistics South Africa 2001 
According to the above information (Figures 2(a) \& 2(b)), the majority of people among AmaZizi were the youth between the ages of 15 and 34 years. This applied to both male and females though females were in the majority while the males were a relatively little represented in relevant category.

This study found that $12 \%$ of respondents interviewed at homes were above the age of fifty ( 53 and above) and the highest percentage was sixty-five and above at $23.5 \%$. While both categories represented people that were out of the labour market, the last category represented pensioners. The category in the fifties represents people that should be still in their working ages, but for various reasons they were not economically active. Given the high levels of illiteracy among the adult population in the study area of AmaZizi (Stats SA 2001), we can deduce that these people did not get to acquire the necessary skills while they were still young so that in their last working ages the labour market has little value for them. At this point, age ceases to be an asset and it becomes a liability if an individual does not possess the capabilities the markets require.

\section{Education as Human Capital Endowments among AmaZizi}

In Figure 2 we show the levels of educational acquisition among AmaZizi as representing a specific category of capital assets necessary for socio-economic development.

Figure 2: Levels of education AmaZizi

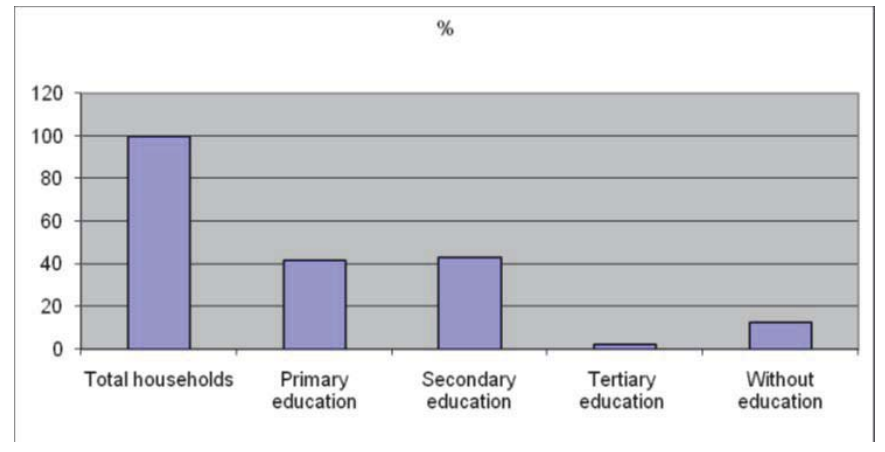

Source: Mazibuko 2010:138.

As figure 2 shows, there are a number of people with secondary school education (43.3\%) in the area of AmaZizi. However, a very small fraction (2.3\%) of the population has enjoyed tertiary education beyond school level. The levels of education are critical for economic development. The benefits of higher education do not only apply to individuals, but as Moretti (2004, p656) and Michaud \& Vencatachellum (2003, p605) explain education has its own externalities; some people benefit from those who possess better skills. Working alongside skilled people (ie better educated people) could help less or semi-skilled people to learn from them. The problem identified at the beginning of this study was that the area of AmaZizi was characterised by unemployment and poverty because of, among other things, a lack of higher education. In this situation, knowledge is severely limited. As shown earlier, the people in this area also pointed out that they did not have the necessary knowledge and skills to meaningfully take part in the local tourism industry. Adding the level of illiteracy at $12.6 \%$, it follows that the area is severely challenged in terms of economic development.

Pencavel (1991, p339) and Moretti (2004, p656) state that schooling and/or education can increase the productive potential of an economy. The increase is not only attributable to the schooled and trained labour force, but can also happen by means of education spill-over or its externalities as indicated above. Externality occurs when the trained labour force passes its skills on to the less-skilled members of the workforce, especially in high-technology areas. Among AmaZizi, the percentage of people who have higher education is very low, with the result that technological know-how in the area is severely limited. It could be argued that if people possessed the necessary skills, their economic conditions would have been better. They would have been able to use their skills to induce economic development in the area, especially since there is sizeable number of people with secondary school education. It is our submission that externalities of human capital (education in particular) can better impact development when they absorbed by the young.

The importance that this article attaches to the whole understanding of capital assets, and human capital asset in 
particular, can be represented in the following formula:

$$
\begin{aligned}
& \mathrm{HC}=f(\mathrm{e}+\mathrm{s}+\mathrm{h}+\mathrm{a}) \\
& \text { where: } \\
& \mathrm{HC}=\text { human capital } \\
& \mathrm{e}=\text { education } \\
& \mathrm{s}=\text { skills } \\
& \mathrm{h}=\text { health, and } \\
& \mathrm{a}=\text { biological age }
\end{aligned}
$$

\section{Conclusion and Implications}

Human capital, as expressed in the SLA, has little meaning if people are aged and possess only their physical labour power with little or no skills. In such a case, people can only become a liability at later stages instead of being assets. These goals are achievable if people are provided with skills when they are still young and better able to learn. Through the skills they acquire at youth, people are empowered to ensure better futures at old age when they can no longer work. On the other hand, 'neglecting' young ages become more visible at old age when people fail to provide for themselves and become more vulnerable to poverty. To this end, this article concludes that biological age is important for the inclusion in the human capital component of the SLA.

Including the age sub-component into the human capital component of the SLA has huge implications for policymakers such as:

- Increasing the resources to improve especially human capital in rural areas. In this regard, the youth require extra attention.

- Introduce specific policies that favour reduction of inequalities in society and rural education in particular.

- The youth in particular has always been the backbone of rural areas including by sending remittances home. There is therefore a great need for policy alternatives that help reduce levels of unemployment in rural areas.

- The people in rural area have endured hardships over a long period of time without a trace of social services by many governments. Policymakers can exploit this resilience people have against oppression, exploitation and marginalisation to further rural development.

\section{References}

Abbas, Q. \& Mujahid-Mukhtar, E. (2001). The role of human capital in economic growth: a comparative study of Pakistan and India. The Pakistan Development Review, 39 (4), pp451-473.

Carney, D. (1998). Implementing the sustainable rural livelihoods approach, in Sustainable rural livelihoods: what contribution can we make? Edited by D Carney. London: Department for International Development.

Carson, R. C. \& Butcher, J. N. (1992). Abnormal psychology and modern life. 9th edition. Harper Collins: New York.

DFID. (1999). Sustainable livelihoods guidance sheets. www.livelihoods.org/info/guidancesheet. Accessed 07/01/2009.

Greyling, T. \& Huntley, B. J. (1984). Directory of southern African conservation areas. CSIR: Pretoria.

Guillemette, Y. (2003). Slowing down with age: the ominous implications of workforce aging for Canadian living standards. Commentary. New York: C.D. Howe Institute.

Haralambos, M. (1985). Sociology: Themes and perspectives. 2nd edition. Unwin Hyman: London.

Lauer, R. H. (1989). Social problems and the quality of life. Wm C. Brown: lowa.

Machlup, F. (1982). Issues in the theory of human capital: education as investment. Pakistan Development Review, 21 (1), pp1-17.

Mazibuko, S. (2013). Understanding underdevelopment through the sustainable livelihoods approach. Community Development, Vol 44 (2), pp173-186.

Mazibuko, S. G. (2010). Development and pro-poor tourism: The livelihood strategies of Amazizi in northern Drakensberg, KwazuluNatal. PhD Dissertation. University of the Free State. Bloemfontein.

Michaud, P. \& Vencatachellum, D. (2003). Human capital externalities in South Africa. Economic Development and cultural Change, 51 (3), pp603-628.

Moretti, E. (2004). Workers' education, spillovers, and productivity: evidence from plant-level production functions. The American Economic Review, 94 (3), pp656-690.

Nel, E. (2005). Local economic development in South Africa's small towns, in Local economic development in the developing world. Edited by E Nel \& C M Rogerson. Transaction: London, pp253-266.

Pencavel, J. (1991). Higher education productivity and earnings: a review. The Journal of Economic Education, 22 (4), pp331-359.

Pretty, J. (2003). Social capital and connectedness: issues and implications for agriculture, rural development and natural resource management in African, Caribbean and Pacific (ACP) countries. www.cta.int/pubs. Accessed 27/05/ 2008. 
ScooneS, I. (1998). Sustainable rural livelihoods: a framework for analysis. Institute of Development Studies (IDS) Working Paper No. 72.

Sen, A.1999. Development as freedom. Oxford University: Calcutta.

Skirbekk, V. (2003). Age and individual productivity: a literature review. Max Planck Institute for Demographic Research: Rostock, Germany.

Statistics South Africa. Census (2012). Available at www.statssa.gov.za Accessed 09/04/2014.

Statistics South Africa. Census (2001). Available at www.statssa.gov.za Accessed 15/07/2007.

Tauer, T. (1995). Age and farmer productivity. Review of Agricultural Economics, 17 (1), pp 63 - 69.

Van Schalkwyk, A. (2008). Sustainability of service delivery in municipalities in South Africa. Journal of Public Administration. 43 (2.1), pp263 - 275.

Water Research Commission. (2004). Citizens indispensable in modern biodiversity protection. South African Water Research Commission: Pretoria,

Youmans, E.G. (1977). The rural aged. Annals of American Academy of Political and Social Science, 429, pp 81 - 90. 